\title{
AKTIVITAS ANTIKANKER EKSTRAK ETANOL DAUN Rhizopora mucronata TERHADAP LARVA UDANG Artemia salina Leach DAN SEL RAJI
}

\author{
Hartiwi Diastuti ${ }^{1}$, Warsinah ${ }^{2}$, Purwati $^{1}$ \\ ${ }^{1}$ Jurusan MIPA, Fakultas Sains dan Teknik UNSOED \\ ${ }^{2}$ Jurusan Farmasi, Fakultas Kedokteran dan Ilmu-ilmu Kesehatan UNSOED \\ E mail : hartiwidiastuti@yahoo.com, telp. 08170611988
}

\begin{abstract}
The mangrove plant have been long used the people for traditional medicine to cure various diseases, one of them to cancer therapy. Investigation the anticancer potent of $R$. mucronata has not been carried yet. This research was aimed to toxicity test of $R$. mucronta leaf extracts againts Artemia salina Leach, then cytotoxicity test of $R$. mucronata leave extracts againts Raji cancer cells. The extraction of $R$. mucronata leaf was peformed by maseration with ethanol. The ethanol extracts was partitioned with chloroform, ethylacetate and methanol. The ethanol extracts of $R$. mucronata leaf respectively was examined their toxicity againts $A$. salina Leach larv. The toxic exctracts was examined their citotoxicity againts Raji cells. The ethanol extract of $R$. mucronata leaf has toxic character because has $\mathrm{LC}_{50}<1000 \mu \mathrm{g} / \mathrm{mL}$. Toxicity test againts A. salina and citotoxicity test againts Raji cells showed that the chloroform fraction of ethanol extract of $R$. mucronata leaf have highest activity, respectively $\mathrm{IC}_{50}$ value equal to $290,92 \mu \mathrm{g} / \mathrm{mL}$ and $105,56 \mu \mathrm{g} / \mathrm{mL}$. Phytochemical study showed that the active fractions contained flavonoid, terpenoid and alkaloid.
\end{abstract}

Keywords : $\boldsymbol{R}$. mucronata, anticancer, Artemia salina, Raji cells

\section{PENDAHULUAN}

Tanaman mangrove merupakan salah satu sumber bahan obat tradisional yang dapat digunakan sebagai sumber senyawa bioaktif di antaranya golongan tanin, saponin, terpenoid, alkaloid dan steroid dengan aktivitas sebagai anti mikroba, antifungi, antivirus, antitumor, insektisida dan antileukemia (Soetarno, 2000). Menurut Saputra (2000), pemanfaatan tanaman mangrove sebagai bahan obat tradisional telah lama digunakan oleh masyarakat dalam terapi penyakit gastroenteritis dan anti kanker. Bagian tumbuhan yang dapat digunakan sebagai anti kanker adalah kulit batang, akar, daun, bunga dan buah. Warsinah, et. al, (2005) melaporkan hasil penelitian tanaman mangrove famili Rhizophora yaitu ekstrak etanol kulit batang Bruguiera gymnorhiza secara in vitro mampu menghambat pertumbuhan sel kanker Hela dengan nilai $\mathrm{IC}_{50}$ sebesar $301,78 \mu \mathrm{g} / \mathrm{mL}$ dan sel Myeloma dengan $\mathrm{IC}_{50}$ sebesar 582,00 $\mu \mathrm{g} / \mathrm{mL}$, dan senyawa yang terkandung pada ekstrak etanol kulit batang $B$. gymnorhiza adalah terpenoid.

Penelitian terhadap tanaman mangrove famili Rhizophora, di antaranya spesies $R$. mucronata belum banyak dilaporkan, terutama kajian senyawa kimianya yang berpotensi sebagai antikanker. Penelitian ini dimaksudkan untuk melakukan uji pendahuluan ekstrak etanol daun $R$. mucronata sebagai antikanker melalui uji toksisitas terhadap larva udang A. salina Leach (Brine Shrime Lethality Test (BSLT)), yang dilanjutkan dengan uji sitotoksisitas terhadap sel kanker Raji. Sel raji merupakan sel limfosit- $\beta$ yang terinfeksi oleh Eipstein-Barr Virus 
$(E B V)$. Sel yang terinfeksi $E B V$ akan mengekpresikan protein yang menjadikan sel resisten terhadap apoptosis (Komano, et.al 1998).

Penelitian dilakukan dengan cara mengekstraksi serbuk daun $R$. mucronata dengan etanol kemudian difraksinasi dengan beberapa pelarut yang berbeda kepolarannya (kloroform, etil asetat dan metanol). Ekstrak selanjutnya diuji toksisitasnya secara in vitro terhadap larva udang (A. salina Leach). Kemudian ekstrak dengan $\mathrm{LC}_{50}<1000 \mu \mathrm{g} / \mathrm{mL}$ diuji sitotoksisitasnya terhadap sel kanker Raji. Identifikasi kandungan kimia ekstrak aktif daun $R$. mucronata dilakukan dengan uji pereaksi warna (Harborne, 1987)

Manfaat penelitian ini adalah memberikan landasan ilmiah mengenai khasiat anti kanker ekstrak etanol daun $R$. mucronata. Penemuan obat antikanker dengan agen fitoterapi menjadi penting artinya, karena dapat memberikan alternatif terapi dengan biaya yang jauh lebih murah dan seringkali memiliki efek samping yang lebih kecil.

\section{METODE PENELITIAN Bahan} dalam penelitian ini adalah : daun R.mucronata, larva udang Artemia salina Leach, air laut, aquades steril, kultur sel Raji, medium kultur sel (RPMI 1640), natrium bikarbonat, fetal bovin serum (FBS) $10 \% \mathrm{v} / \mathrm{v}$, fungison $0,5 \% \mathrm{v} / \mathrm{v}$, DMSO (dimetilsulfoksida), akridin oranye, etidium bromida, sodium dodesil sulfat (SDS), reagen stopper (natrium dodesil sulfat $10 \%$ v/v dalam $\mathrm{HCl}$ ), MTT [3-(4,5-dimetiltiazol-2-il)-2,5-difenil tetrazolium bromida] $5 \mathrm{mg} / \mathrm{mL}$ dalam FBS, asam asetat glasial, $\mathrm{NH}_{3}$, etanol, metanol, etil asetat, kloroform, $n$ heksana pereaksi Shinoda, pereaksi Liberman Buchard, dan pereaksi Mayer.

\section{Peralatan}

Peralatan yang akan digunakan dalam penelitian ini adalah : mikropipet, autoklaf, well plate 96 sumuran, ELISA reader SLT 340 ATC, rotaryevaporator, inkubator $5 \% \mathrm{CO}_{2}$ suhu $37^{\circ} \mathrm{C}$, laminar air flow, nitrogen cair, mikroskop fluoresensi, dan cell counter.

\section{Prosedur Penelitian}

\section{Ekstraksi daun $\boldsymbol{R}$. mucronata}

Daun $R$. mucronata yang telah dibuat serbuk sebanyak $500 \mathrm{~g}$ diekstraksi dengan etanol dengan cara maserasi selama 2 x 24 jam. Ekstrak etanol selanjutnya diuapkan pelarutnya dengan rotaryevaporator sehingga diperoleh ekstrak etanol tanpa pelarut. Ekstrak etanol kemudian dipartisi (diekstrak kembali) dengan pelarut yang berbeda kepolarannya yaitu berturut-turut dengan kloroform, etil asetat dan metanol. Sehingga diperoleh fraksi kloroform, fraksi etil asetat dan fraksi metanol. Ekstrak etanol dan masing-masing fraksi diuji toksisitasnya terhadap larva $A$. salina Leach kemudian ekstrak yang bersifat toksik terhadap larva A. salina Leach diuji sitotoksisitasnya terhadap sel kanker Raji.

\section{Uji toksisitas terhadap larva $A$. salina Leach}

Telur A. salina direndam ke dalam aquades selama 1 jam, telur yang tenggelam diambil untuk ditetaskan dalam air laut. Penetasan telur udang dilakukan dalam aquarium yang diberi aerasi selama 48 jam. Aquarium dibagi dua bagian dengan sekat kawat kassa. Satu bagian diberi telur udang dan ditutup dengan kertas karbon sedang bagian yang lain diberi penerangan dengan lampu. Larva akan bergerak dari tempat gelap ke tempat terang. Kemudian tabung berisi $10 \mathrm{~mL}$ air laut dan ekstrak disiapkan untuk memindahkan larva sebanyak 10 ekor, kemudian diamati 
berapa larva udang yang mati dan dilanjutkan dengan penghitungan $\mathrm{LC}_{50}$. Dibuat seri kadar ekstrak 1000, 500, 250, 125 dan $62,5 \mu \mathrm{g} / \mathrm{mL}$.

\section{Pembuatan larutan uji untuk uji sitotoksisitas}

Ekstrak sampel yang telah dikering beku (freeze dried) dibuat stok $10 \mathrm{mg} / \mathrm{mL}$ dengan melarutkan sampel dalam DMSO 0,25\% v/v dalam aquades steril. Larutan uji disaring dengan filter $0,2 \mu \mathrm{m}$, kemudian dimasukkan dalam conical steril ditutup dengan parafilm, dan disimpan dalam lemari es. Dibuat seri kadar ekstrak dari larutan stok dalam medium RPMI 1640. Pembuatan larutan uji dilakukan di dalam laminar air flow cabinet secara aseptis, dengan seri kadar ekstrak 500, 250, 125, 62,5 dan 31,25 $\mu \mathrm{g} / \mathrm{mL}$.

\section{Uji sitotoksisitas dengan metode MTT}

Sebanyak $100 \mu \mathrm{L}$ suspensi sel uji dengan kepadatan $2 \times 10^{4} / 100 \quad \mu \mathrm{L}$ didistribusikan ke dalam well plate 96 sumuran dan ditambah ekstrak uji dengan seri kadar di atas. Sebagai pembanding $100 \mu \mathrm{L}$ sel uji dimasukkan ke dalam sumuran yang berisi doksorubisin. Sebagai kontrol $100 \mu \mathrm{L}$ suspensi sel diganti $100 \mu \mathrm{L}$ medium dan untuk blanko digunakan $95 \mu \mathrm{L}$ suspensi sel ditambah $5 \mu \mathrm{L}$ DMSO 0,25\% v/v dalam medium. Selanjutnya dilakukan inkubasi selama 24 jam pada suhu $37{ }^{\circ} \mathrm{C}$. Pada akhir inkubasi ke dalam sumuran ditambahkan $10 \mu \mathrm{l}$ MTT $5 \mathrm{mg} / \mathrm{mL}$ dalam medium. Sel uji yang hidup akan bereaksi dengan MTT membentuk warna ungu. Reaksi dengan MTT dihentikan dengan reagen stopper. Kemudian diinkubasi 24 jam pada suhu kamar, serapan dibaca dengan ellisa reader pada panjang gelombang $550 \mathrm{~nm}$.

\section{Pengecatan DNA}

Pada akhir inkubasi (jam ke 24), sel dalam medium diambil, difiksasi dengan formaldehida kemudian ditambahkan etidium bromida-akridin oranye $0,1 \%$ v/v. Sel diamati di bawah mikroskop flourosensi.

\section{Uji fitokimia ekstrak tanaman}

\section{Uji flavonoid}

Larutan sampel ditambah dengan serbuk magnesium (pereaksi Shinoda) kemudian diberi beberapa tetes $\mathrm{HCl}$ pekat. Adanya senyawa flavonoid ditunjukkan dengan timbulnya warna oranye, merah muda dan ungu.

\section{Uji terpenoid}

Ke dalam larutan Lieberman Buchard diteteskan larutan sampel. Adanya senyawa terpenoid ditunjukkan dengan timbulnya warna biru, hijau, merah atau oranye.

\section{Uji alkaloid}

Larutan sampel ditambah dengan pereaksi Mayer selanjutnya ditambah beberapa tetes asam. Adanya alkaloid ditunjukkan dengan timbulnya endapan putih sampai kekuningan.

\section{HASIL DAN PEMBAHASAN Ekstraksi Tanaman $R$. mucronata}

Ekstraksi dilakukan dengan cara maserasi sebanyak $500 \mathrm{~g}$ daun $R$. mucronata dengan etanol selama $2 \times 24$ jam. Setelah diuapkan pelarutnya diperoleh ekstrak etanol daun R.mucronata sebanyak 32,75 g.

Ekstraksi partisi dari ekstrak etanol daun (10 g) $R$. mucronata masingmasing dengan pelarut yang berbeda kepolaranya yaitu kloroform, etil asetat dan metanol, dimaksudkan untuk memisahkan senyawa yang terlarut dalam etanol berdasarkan kepolarannya. Hasil ekstraksi partisi ekstrak etanol dengan 
pelarut kloroform, etil asetat dan metanol disajikan pada Tabel 1 berikut :

Tabel 1. Hasil ekstraksi partisi ekstrak etanol daun $R$. Mucronata

\begin{tabular}{ll}
\hline Fraksi & Berat $(\mathrm{g})$ \\
\hline Kloroform & 1,56 \\
Etil asetat & 2,26 \\
Metanol & 4,05
\end{tabular}

Masing-masing ekstrak selanjutnya diuji toksisitasnya terhadap larva udang $A$. salina Leach, sebagai tahap awal uji antikanker.

\section{Uji Toksisitas terhadap Larva $A$. salina Leach}

Uji toksisitas ekstrak etanol, fraksi kloroform, fraksi etil asetat, dan fraksi metanol daun $R$. mucronata dilakukan dengan memasukkan 10 ekor larva udang $A$. salina Leach yang telah berumur 48 jam. Berdasarkan hasil uji diperoleh data jumlah larva udang hidup setelah diinkubasi 24 jam dengan ekstrak uji pada berbagai konsentrasi (Lampiran 1). Nilai $\mathrm{LC}_{50}$ dari masing-masing ekstrak diperoleh dari hasil perhitungan log konsentrasi terhadap nilai probit. Nilai LC $_{50}$ dari masing-masing ekstrak disajikan pada Tabel 2 berikut :

Tabel 2. Nilai LC $_{50}$ ekstrak daun $R$. mucronata.

\begin{tabular}{ll}
\hline Ekstrak & $\begin{array}{l}\mathrm{LC}_{50} \\
(\mu \mathrm{g} / \mathrm{mL})\end{array}$ \\
\hline Etanol & 416,01 \\
Fraksi kloroform & 290,92 \\
Fraksi etil asetat & 292,46 \\
Fraksi metanol & 339,97 \\
\hline
\end{tabular}

Berdasarkan Tabel di atas diketahui bahwa ekstrak etanol daun $R$. mucronata memiliki nilai $\mathrm{LC}_{50}$ di bawah $1000 \mu \mathrm{g} / \mathrm{mL}$ yaitu $416,01 \mu \mathrm{g} / \mathrm{mL}$. Hal ini menunjukkan bahwa ekstrak etanol daun
R. mucronata bersifat toksik terhadap larva $A$. salina Leach.

Sedangkan hasil ekstraksi partisi, fraksi etil asetat dan fraksi kloroform menunjukkan toksisitas yang relatif lebih tinggi dari ekstrak metanol yaitu masingmasing memiliki nilai $\mathrm{LC}_{50}$ sebesar $290,92 \mu \mathrm{g} / \mathrm{mL}$ dan 292,46 $\mu \mathrm{g} / \mathrm{mL}$. Berdasarkan nilai $\mathrm{LC}_{50}$ hasil uji toksisitas terhadap larva A.salina Leach, maka dilakukan uji selanjutnya yaitu uji sitotoksisitas terhadap sel kanker Raji.

\section{Uji Sitotoksisitas Terhadap Sel Kanker}

Tingkat sitotoksisitas ekstrak uji terhadap sel kanker dapat dinyatakan dengan nilai $\mathrm{IC}_{50}$. $\mathrm{IC}_{50}$ merupakan acuan untuk melakukan uji lebih lanjut yaitu pengecatan DNA. Uji sitotoksisitas pada penelitian ini dilakukan dengan menggunakan metode MTT.

Hasil uji sitotoksisitas terhadap sel Raji, berdasarkan data yang diperoleh secara umum menunjukkan bahwa persentase kematian sel kanker menurun dengan semakin menurunnya konsentrasi ekstrak uji. Hal ini menunjukkan potensi ketoksikan ekstrak adalah dose dependent (tergantung dosis) (Da'i, 2003).

Data yang diperoleh dari hasil uji MTT (Lampiran 2) selanjutnya digunakan untuk menghitung nilai $\mathrm{IC}_{50}$ dengan menggunakan analisis probit. Hasil perhitungan diperoleh nilai $\mathrm{IC}_{50}$ ekstrak etanol kulit daun $R$. mucronata terhadap sel kanker Raji seperti pada Tabel 3.

Berdasarkan Tabel 3 di atas diketahui bahwa ekstrak etanol daun $R$. mucronata bersifat sitotoksik terhadap sel Raji dengan nilai $\mathrm{IC}_{50}$ sebesar 649,36 $\mu \mathrm{g} / \mathrm{mL}$. Sedangkan fraksi yang memiliki aktivitas paling tinggi adalah fraksi kloroform daun $R$. mucronata dengan nilai $\mathrm{IC}_{50}$ sebesar $105,56 \mu \mathrm{g} / \mathrm{mL}$. 
Tabel 3. Nilai $\mathrm{LC}_{50}$ ekstrak etanol daun $R$. mucronata terhadap sel kanker Raji.

\begin{tabular}{ll}
\hline Ekstrak & $\begin{array}{l}\mathrm{IC}_{50} \\
\mu \mathrm{g} / \mathrm{mL}\end{array}$ \\
& \\
\hline Etanol & 649,36 \\
Fraksi kloroform & 105,56 \\
Fraksi etil asetat & 983,34 \\
Fraksi metanol & 171,30 \\
\hline
\end{tabular}

\section{Pengecatan DNA}

Pengecatan DNA dengan etidium bromida-akridin oranye adalah uji kualitatif untuk mengetahui adanya kematian sel yang telah diujikan atau sering disebut apoptosis, dengan melihat perubahan warna pada sel yang mengalami apoptosis. Apoptosis merupakan suatu proses fisiologi eliminasi sel yang tidak diinginkan dan tidak berguna selama proses pertumbuhan sel dan proses biologi sel lainnya. Peristiwa apoptosis sel secara teknis sulit diamati. Apoptosis ditunjukkan dari gambaran morfologi selnya, seperti pengerutan sel, pembengkakan pada membran, kondensasi kromatin, dan fragmentasi nukleus (Wyllie, et al,. 2000)

Pengecatan DNA dengan perlu dilakukan untuk menunjukkan bahwa sel yang mati benar-benar disebabkan oleh efek toksik dari ekstrak yang diujikan yaitu ekstrak etanol $R$. mucronata, bukan dari pemberian dosis atau kadar yang terlalu tinggi. Pengecatan DNA dilakukan dengan menginkubasi masing-masing sel uji dengan perlakuan fraksi kloroform ekstrak etanol daun $R$. mucronata dibandingkan dengan kontrol positif. Hasil pengecatan DNA terhadap sel Raji dapat dilihat pada Gambar 1.

Hasil pengecatan DNA menunjukkan adanya peristiwa apoptosis yang dialami oleh sel kanker Raji. Hal ini ditunjukkan dengan adanya sel berwarna jingga pada perlakuan dengan fraksi kloroform daun $R$. mucronata, sedangkan pada kontrol positif menunjukkan sel tetap hidup yang ditunjukkan dengan sel berwarna hijau terang.

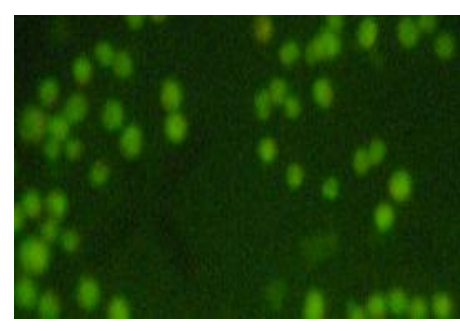

(a)

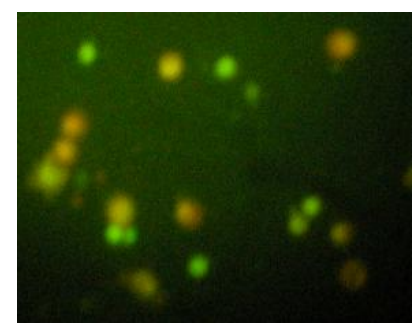

(b)

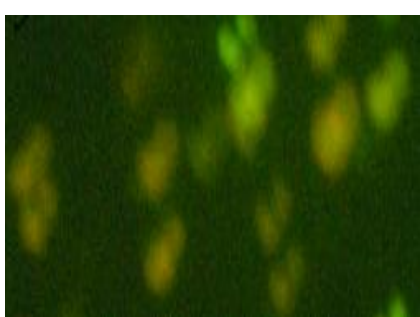

(c)

Keterangan : (a) Sel kontrol Raji berbentuk bulat (warna hijau)

(b) Sel Raji mati setelah perlakuan dengan ekstrak etanol mengalami apoptosis (warna jingga)

(c) Sel Raji mati setelah perlakuan dengan fraksi kloroform mengalami apoptosis (warna jingga)

Gambar 1. Sel Raji dengan perlakuan sampel ekstrak daun $R$. mucronata 


\section{Uji Fitokimia Ekstrak Aktif}

Uji kualitatif golongan senyawa kimia (fitokimia) dimaksudkan untuk mengetahui komponen kimia dari fraksi aktif yaitu fraksi kloroform dari ekstrak etanol daun $R$. mucronata yang berpotensi sebagai antikanker. Hasil uji dengan pereaksi warna menunjukkan bahwa fraksi kloroform ekstrak etanol daun $R$. mucronata positif terhadap uji terpenoid dan alkaloid. Hasil uji fitokimia dapat dilihat pada Tabel 4 berikut:

Tabel 4. Hasil Uji kualitatif golongan senyawa ekstrak etanol $R$. mucronata

\begin{tabular}{llll}
\hline Sampel & Flavonoid & Terpenoid & Alkaloid \\
\hline Fraksi kloroform & + (merah-ungu $)$ & + (biru-ungu $)$ & $++($ kuning $)$ \\
& & & \\
\hline
\end{tabular}

\section{KESIMPULAN}

Berdasarkan hasil penelitian diperoleh kesimpulan bahwa ekstrak etanol daun $R$. mucronata berpotensi sebagai antikanker. Aktivitas antikanker tertinggi ditunjukkan oleh fraksi kloroform dengan nilai $\mathrm{LC}_{50}$ sebesar $290,92 \mu \mathrm{g} / \mathrm{mL}$ terhadap A. salina dan nlai $\mathrm{IC}_{50}$ sebesar $105,56 \mu \mathrm{g} / \mathrm{mL}$ terhadap sel Raji. Hasil uji fitokimia menunjukkan bahwa fraksi kloroform dari ekstrak etanol daun R.mucronata mengandung senyawa flavonoid, terpenoid dan alkaloid.

\section{UCAPAN TERIMAKASIH}

Ucapan terimakasih kami sampaikan kepada DP2M DIKTI yan telah mendanai penelitian melalui program Hibang Bersaing.

\section{DAFTAR PUSTAKA}

Anonim. 2004. Kanker dan Karakteristiknya. $\quad$ www. Changajaya-abidi (online) diakses 14 Februari 2005.
---------.2005. Profil Kesehatan Indonesia. Departemen Kesehatan Republik Indonesia, Pusat Data Kesehatan. Jakarta. pp 21-25.

Dai, M. 2003. Uji Aktivitas Anti Proliferatif Pentagamavunon-O terhadap Sel Raji, Sel Hela dan Sel Myeloma. Tesis. Fakultas Farmasi UGM. Yogjakarta (tidak dipublikasikan).

Harborne JB, 1987, Metode Fitokimia Penuntun Modern Menganalisis Tumbuhan, Edisi II, Penerbit ITB. Bandung.

Komano, J. Sugiura M, and Takada K. 1998. Epstein-Barr Virus Contributes to The Malignant Phenotype and to Apoptosis Resistance in Burkitt's Limphoma cell line Akata. Journal of Virology. 72(11):9150-9156.

Ma'at, S. 2004. Obat Tradisional untuk Pelayanan Kesehatan Formal. Prosiding Seminar Nasional. Tanggal 5 September 2004 di Surabaya. 45-49. 
Saputra, K., Ma'at, S., and Soedoko, R., 2000. Terapi Biologi Untuk Kanker. Airlangga University Press. Surabaya.

Soetarno, S. 2000. Potensi dan Manfaat Tumbuhan Mangrove sebagai Sumber Bahan Bioaktif. Acta Pharmaceutica Indonesia. 12(4):84-103.

Warsinah, Puji L., Trisnowati, 2005, Isolasi Senyawa Bioaktif pada Kulit
Batang B. gymnorhiza Sebagai

Bahan Antikanker. Laporan Penelitian Dasar. Tidak dipublikasikan.

Wyllie, A., Donahue, V., Fisher, B., Hill, D., Keesey, J. and Manzow, S. 2000. Cell Death Apoptosis and Necrosis. Rosche Diagnosis Coorporation, 2-64 
Aktivitas Antikanker...(Hartiwi Diastuti, dkk.)

Lampiran 1. Data uji toksisitas ekstrak etanol daun $R$. mucronata terhadap A. salina

\begin{tabular}{|c|c|c|c|c|c|}
\hline Ekstrak & $\begin{array}{c}\text { Konsentrasi } \\
(\mu \mathrm{g} / \mathrm{mL})\end{array}$ & $\begin{array}{l}\text { Rata-rata } \\
\text { hidup }\end{array}$ & $\%$ mati & log. kons & $\begin{array}{c}\mathbf{L C}_{50} \\
(\mu \mathrm{g} / \mathrm{mL})\end{array}$ \\
\hline Etanol & $\begin{array}{c}1000 \\
500 \\
250 \\
125 \\
62,5\end{array}$ & $\begin{array}{l}5,67 \\
7,00 \\
8,00 \\
8,67 \\
9,33\end{array}$ & $\begin{array}{c}43,30 \\
30,00 \\
20,00 \\
13,30 \\
6,70\end{array}$ & $\begin{array}{l}3,00 \\
2,70 \\
2,40 \\
2,10 \\
1,80\end{array}$ & 416,00 \\
\hline $\begin{array}{l}\text { Fraksi } \\
\text { kloroform }\end{array}$ & $\begin{array}{c}1000 \\
500 \\
250 \\
125 \\
62,5\end{array}$ & $\begin{array}{l}3,33 \\
4,33 \\
5,67 \\
5,67 \\
6,00\end{array}$ & $\begin{array}{l}66,70 \\
56,70 \\
43,30 \\
43,30 \\
40,00\end{array}$ & $\begin{array}{l}3,00 \\
2,70 \\
2,40 \\
2,10 \\
1,80\end{array}$ & 290,92 \\
\hline $\begin{array}{l}\text { Fraksi } \\
\text { Etil asetat }\end{array}$ & $\begin{array}{c}1000 \\
500 \\
250 \\
125 \\
62,5\end{array}$ & $\begin{array}{l}1,33 \\
2,33 \\
3,67 \\
4,33 \\
5,33\end{array}$ & $\begin{array}{l}86,70 \\
76,70 \\
63,30 \\
56,70 \\
46,70\end{array}$ & $\begin{array}{l}3,00 \\
2,70 \\
2,40 \\
2,10 \\
1,80\end{array}$ & 292,46 \\
\hline $\begin{array}{l}\text { Fraksi } \\
\text { metanol }\end{array}$ & $\begin{array}{c}1000 \\
500 \\
250 \\
125 \\
62,5\end{array}$ & $\begin{array}{l}2,33 \\
3,67 \\
4,33 \\
7,67 \\
8,00\end{array}$ & $\begin{array}{l}76,70 \\
63,30 \\
56,70 \\
23,30 \\
20,00\end{array}$ & $\begin{array}{l}3,00 \\
2,70 \\
2,40 \\
2,10 \\
1,80\end{array}$ & 333,96 \\
\hline
\end{tabular}


Molekul, Vol. 4. No. 1. Mei, 2009 : 12 - 20

Lampiran 2. Data uji sitotoksisitas ekstrak etanol daun $R$. mucronata terhadap sel Raji

\begin{tabular}{cccccc}
\hline Ekstrak & $\begin{array}{c}\text { Konsentrasi } \\
(\boldsymbol{\mu g} / \mathbf{m L} \mathbf{)}\end{array}$ & $\begin{array}{c}\text { Rata-rata } \\
\text { absorbansi }\end{array}$ & \% mati & log. kons & $\begin{array}{c}\mathbf{I C}_{\mathbf{5 0}} \\
(\boldsymbol{\mu g} \mathbf{m} \mathbf{m})\end{array}$ \\
\hline \multirow{2}{*}{ Etanol } & 500 & 0,624 & 11,658 & 2,70 & \\
& 250 & 0,655 & 5,950 & 2,40 & \\
& 125 & 0,723 & 0 & 2,10 & 649,36 \\
& 62,5 & 0,690 & 0 & 1,80 & \\
Fraksi & 31,25 & 0,705 & 0 & 1,48 & \\
kloroform & 500 & 0,310 & 68,913 & 2,70 & \\
& 250 & 0,443 & 44,566 & 2,40 & \\
& 125 & 0,491 & 35,883 & 2,10 & 105,56 \\
Fraksi & 62,5 & 0,527 & 29,326 & 1,80 & \\
Etil asetat & 31,25 & 0,622 & 12,083 & 1,48 & \\
& 500 & 0,660 & 2,161 & 2,70 & \\
& 250 & 0,675 & 2,249 & 2,40 & \\
& 125 & 0,752 & 0 & 2,10 & 983,30 \\
Fraksi metanol & 62,5 & 0,809 & 0 & 1,80 & \\
& 31,25 & 0,844 & 0 & 1,48 & \\
& 500 & 0,499 & 53,127 & 2,70 & \\
Kontrol & 250 & 0,496 & 37,158 & 2,40 & 171,30 \\
Medium & 125 & 0,596 & 21,736 & 2,10 & \\
\hline
\end{tabular}

